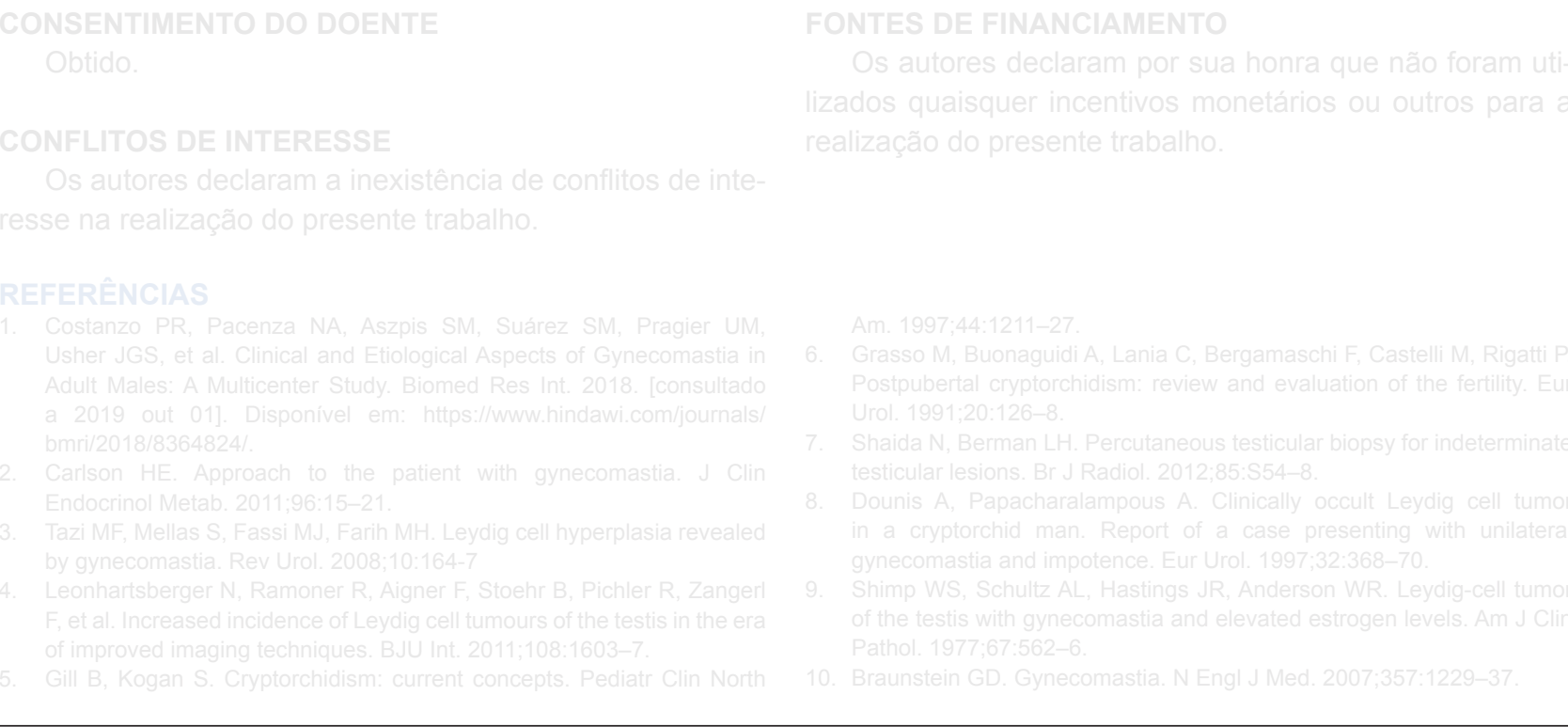

\title{
Post Vaccine Rubella During a Measles Outbreak: Clinical Case
}

\section{Rubéola Pós-Vacina Durante um Surto de Sarampo: Caso Clínico}

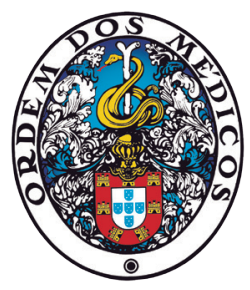

\author{
Luísa GRAÇA $\square^{1,2}$, Sara PEREIRA 1 , Raquel DURO ${ }^{1,3}$, António SARMENTO ${ }^{1,3}$ \\ Acta Med Port 2021 Feb;34(2):139-142 • https://doi.org/10.20344/amp.12670
}

\section{ABSTRACT}

Rubella is a vaccine preventable infection, and congenital rubella the most feared complication of this disease. Although young adult women are at greatest risk of post-vaccine rubella, this is also the group who potentially benefits the most from vaccine protection. Since post-vaccine disease has a mild and self-limited course, the benefit clearly exceeds the risk. During a measles outbreak in the north of Portugal, a 38-year-old woman presented with cervical posterior lymphadenopathies, fever and a maculo-papular rash one week after the administration of the measles, mumps and rubella vaccine. Measles was discarded and rubella viremia was demonstrated. Symptoms of rubella are non-specific and laboratory confirmation is essential. This is particularly relevant during a measles outbreak. Keywords: Disease Outbreaks; Measles; Measles-Mumps-Rubella Vaccine; Rubella

\section{RESUMO}

A rubéola é uma infeção prevenível por vacina, sendo a rubéola congénita a apresentação mais grave da doença. Apesar de serem o grupo que mais beneficia dela, as mulheres em idade fértil são também o grupo com maior risco de doença associada à vacina. Uma vez que as manifestações clínicas são ligeiras e transitórias, o benefício compensa largamente o risco.

Durante o surto de sarampo que ocorreu no Porto em 2018, uma mulher de 38 anos recebeu a primeira dose da vacina contra o sarampo, rubéola e papeira. Uma semana depois, recorreu ao Serviço de Urgência por febre, exantema maculo-papular e adenopatias cervicais posteriores. Foi excluído sarampo e demonstrada viremia pelo vírus da rubéola. Os sintomas da rubéola são inespecíficos pelo que a confirmação laboratorial é essencial. Isto é ainda mais relevante em contexto de surto de sarampo.

Palavras-chave: Rubéola; Sarampo; Surtos de Doença; Vacina contra Sarampo-Parotidite-Rubéola

\section{INTRODUCTION}

German measles or rubella is a preventable viral disease. ${ }^{1}$ Although postnatally acquired rubella is usually mild, the congenital infection is associated with major complications (neonatal purpura, central nervous system deficits, heart disease, deafness and blindness). ${ }^{1}$ The major goal of the vaccine is to prevent this syndrome. ${ }^{2}$

The vaccine was introduced in the Portuguese immunisation schedule in 1984 and is now administered as mumps measles rubella (MMR) vaccine, which is safe and effective. ${ }^{3}$ Although fewer than 10 cases of rubella are reported

1. Serviço de Doenças Infecciosas. Centro Hospitalar e Universitário de São João. Porto. Portugal.

2. Departamento de Doenças Infecciosas. Faculdade de Medicina. Universidade do Porto. Porto. Portugal.

3. Unidade de Prevenção e Controlo de Infecção e Resistência aos Antimicrobianos. Centro Hospitalar e Universitário de São João. Porto. Portugal.

$\triangle$ Autor correspondente: Luísa Graça. aluisacgraca@gmail.com

Recebido: 08 de agosto de 2019 - Aceite: 12 de setembro de 2019 - First published: 05 de dezembro de 2019 - Online issue published: 01 de fevereiro de 2021 Copyright $\odot$ Ordem dos Médicos 2021 
annually in our country and the MMR vaccine coverage is stated to be above $95 \%,{ }^{3}$ recent measles outbreaks in Portugal should raise the concern for a possible resurgence of rubella. ${ }^{3}$ In order to maximize the vaccine coverage nationwide, and especially during an outbreak situation, opportunistic vaccination is an important measure.

While rubella presents more frequently with joint pain and cervical posterior lymphadenopathies, there is no pathognomonic sign and the clinical diagnosis is unreliable. ${ }^{1}$ The epidemiologic context is critical in outlining the differential diagnosis. The list is extensive and includes parvovirus B19, roseola infantum, measles and dengue among others. ${ }^{1}$ Considering the rising incidence of measles in Europe, it is the most frequent misdiagnosis to be considered, not only for rubella caused by wild virus but also the disease caused by vaccine virus. ${ }^{4}$ Post-vaccine rubella is more common in young women receiving the first dose of MMR vaccine,$^{5}$ a regular practice during measles outbreaks, when MMR vaccine campaigns for adults are implemented. ${ }^{4}$

We report a case of rubella probably caused by vaccine virus that occurred during a measles outbreak. Our objective is to increase the clinical awareness to this rare diagnosis.

\section{CASE REPORT}

A 38-year-old female patient with previous medical history of thyroid papillary carcinoma, submitted to thyroidectomy and treated with levothyroxine, presented to the emergency department with fever and an exanthematous eruption.

She had no history of measles nor prior vaccine record and denied contact with sick people. During a measles outbreak she was opportunistically vaccinated with the MMR vaccine. A week later she reported cervical posterior lymphadenopathies about $2 \mathrm{~cm}$ wide (Fig. 1), a mild non-pruritic maculopapular rash that spread cephalo-caudally (Fig. 2), fever (maximum $38.3^{\circ} \mathrm{C}$ ) and bilateral conjunctivitis. She had no arthralgia, rhinitis or cough. On physical examination there were no Koplik or Forchheimer spots.

Rubella virus was detected in blood by nucleic acid amplification test (NAAT). The test was negative in oral secretions and urine. The detection of measles virus by NAAT in oral fluids, blood and urine was negative as well as measles IgM antibody. Measles IgG antibody was positive.

The patient was treated symptomatically with antipyretics and recovered uneventfully in a few days. On followup visit (two weeks after vaccination) she reported de novo mild arthralgia without arthritis of the elbow and wrist that also subsided over a few weeks.

\section{DISCUSSION}

Congenital rubella is associated with major complications, particularly if acquired early during pregnancy. The vaccine, which is safe and effective, is the most important preventive measure. $^{1}$

Post vaccination rubella, while rare in children, occurs in up to $50 \%$ of women older than 30 years and is more common after the first dose of the vaccine. ${ }^{5,6}$ Vaccine recipients present with fever, rash and lymphadenopathies one week after the administration. ${ }^{5,6}$ Mild and transient arthralgia and arthritis, although rarer $(25 \%$ of post-pubertal women getting the first dose of vaccine) can also occur. ${ }^{5,6}$

Considering that clinical diagnosis is unreliable, laboratory confirmation is essential. ${ }^{1,2}$ This is of particular significance during a measles outbreak since it has important public health implications.

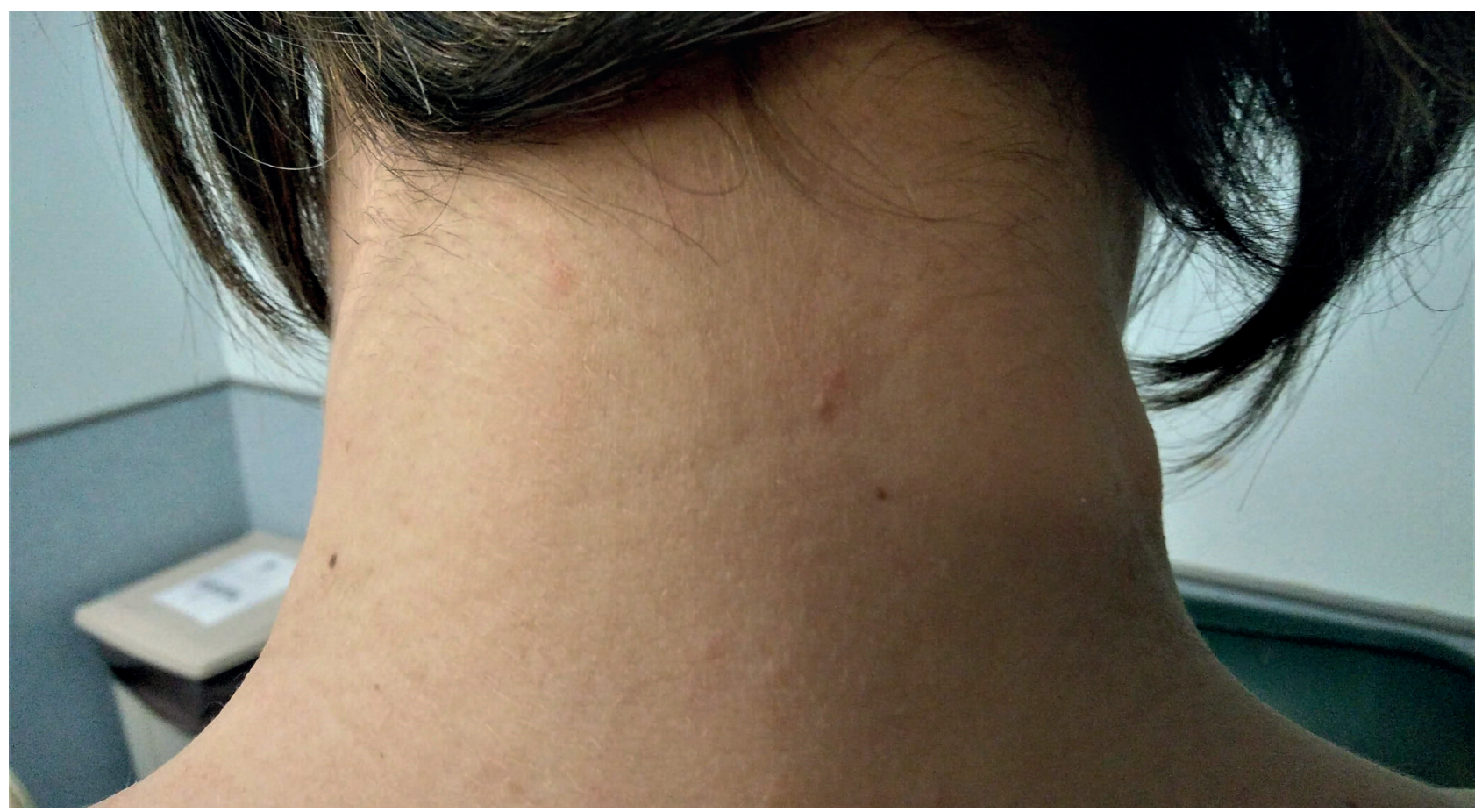

Figure 1 - Cervical posterior lymphadenopathies 


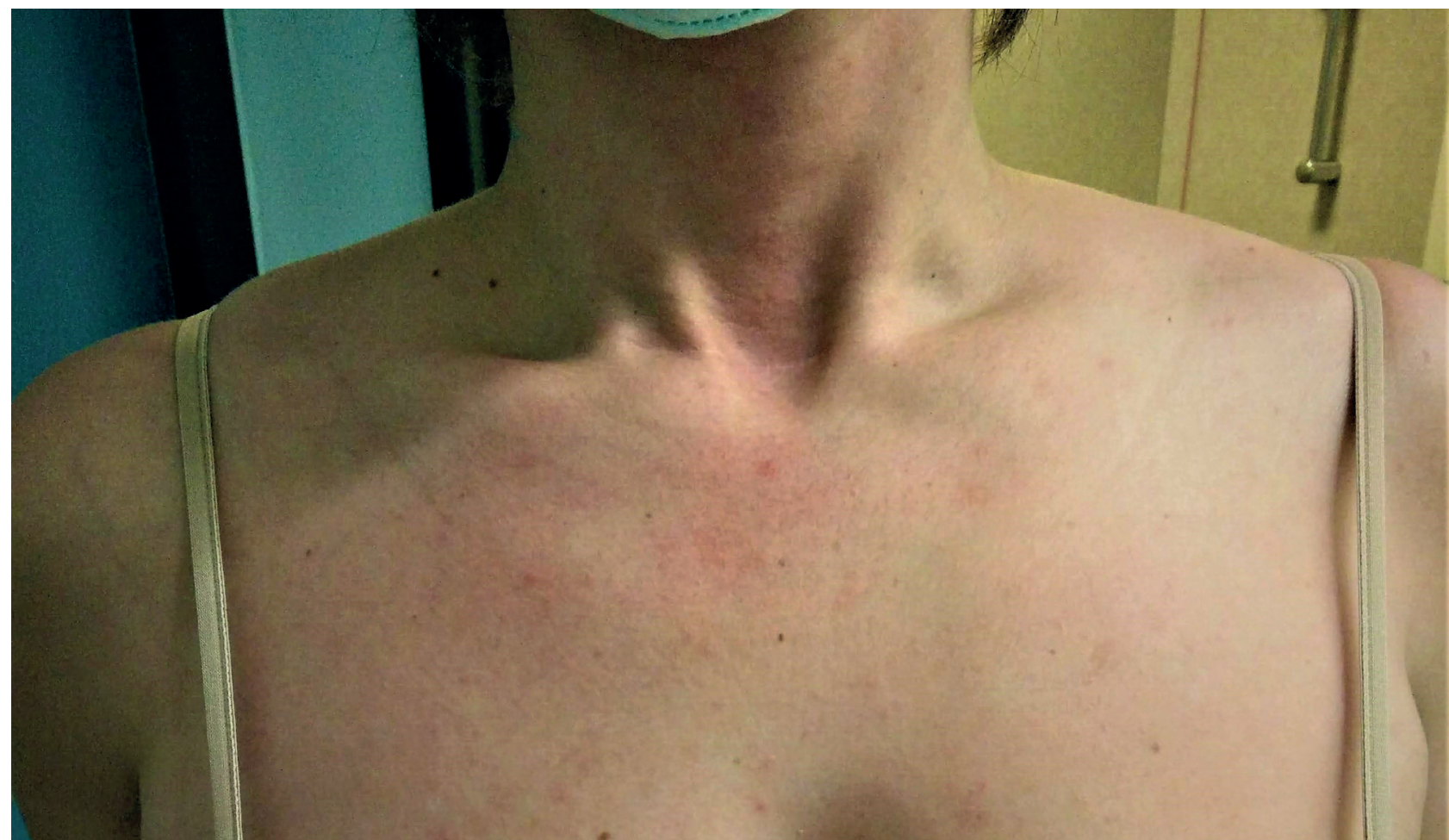

Figure 2 - Subtle maculopapular rash

Rubella and measles have very similar clinical presentations. ${ }^{1}$ Both present with fever and maculo-papular rash that spreads cephalo-caudally and although characteristically measles presents with a prodrome of conjunctivitis, rhinitis and cough and rubella presents with milder symptoms, cervical posterior lymphadenopathies and arthralgia, clinical distinction is unreliable, especially in vaccine recipients which have atypical and milder presentations of measles..$^{1,4}$ Koplik spots are pathognomonic of measles but are short lived and frequently missed. ${ }^{4}$

Both measles and rubella were traditionally diagnosed by serology (positive IgM antibody) but detection of the virus by NAAT in blood, urine and oral fluids is increasingly used. ${ }^{2,4}$ In our case the diagnosis was established by detection of viremia. Vaccine and wild-type virus can be distinguished in specialized laboratories. ${ }^{2}$

Vaccination is followed by viremia between day 7 and 11 and early production of IgM antibodies peaks at one month and lasts approximately two. ${ }^{6}$ Although the virus is frequently detected in the nasopharynx of vaccine recipients, it is of low level and no contact spread has been demonstrated. ${ }^{6}$

Since measles IgG was positive and IgM was negative, we presume that our patient was already immune to measles by the time the vaccine was administered.

Anti-vaccination groups are becoming more frequent in Europe. As a consequence, the number of adults not vaccinated will potentially rise over time. Outbreaks will become more frequent, as well as currently rare clinical syndromes associated with vaccination in adults as the one described, making their awareness relevant for clinicians.

Although the adverse events of MMR vaccine are more common in women of childbearing age, they are usually mild and transient. On the contrary, congenital rubella is a devastating disease. Being so, all women of childbearing age without evidence of previous vaccination should be tested for rubella immunity and vaccinated if unprotected. Since MMR vaccine uses live attenuated virus, it is contraindicated in pregnant woman and immunocompromised patients. It should be given at least one month prior to conception or initiation of immunosuppressant drugs, or during the postpartum period. In conclusion, the benefits of the vaccine largely exceed the risk of adverse events and it should not be withheld.

\section{PROTECTION OF HUMANS AND ANIMALS}

The authors declare that the procedures were followed according to the regulations established by the Clinical Research and Ethics Committee and to the Helsinki Declaration of the World Medical Association.

\section{DATA CONFIDENTIALITY}

The authors declare having followed the protocols in use at their working center regarding patients' data publication.

\section{INFORMED CONSENT}

Obtained.

\section{CONFLICTS OF INTEREST}

All authors report no conflict of interest.

\section{FUNDING SOURCES}

The authors declare that there were no external sources of study for the performance of this article. 


\section{REFERENCES}

1. Banatvala JE, Brown DW. Rubella. Lancet. 2004;363:1127-37.

2. Lambert N, Strebel P, Orenstein W, Icenogle J, Poland GA. Rubella. Lancet. 2015;385:2297-307.

3. Direção-Geral da Saúde. Lisboa. 2016. [consulted 2019 Apr 30]. Available from: http://whttps://www.dgs.pt/saude-publica1/vacinacao. aspxww.dgs.pt/saude-publica1/vacinacao.aspx.
4. Moss WJ. Measles. Lancet. 2017;390:2490-502.

5. Kowalzik F, Faber J, Knuf M. MMR and MMRV vaccines. Vaccine. 2018;36:5402-7.

6. Reef SE, Plotkin S. Rubella vaccine. In: Plotkin S, Orenstein W, Offit P, editors. Vaccines. $6^{\text {th }}$ ed. Philadelphia: Elsevier; 2013. p. 668-717. 